Gulya Nikoletta ${ }^{1}$ - Szivák Judit ${ }^{2}$ - Fehérvári Anikó ${ }^{3}$

${ }^{1}$ ELTE PPK Neveléstudományi Doktori Iskola

${ }^{2}$ ELTE PPK Neveléstudományi Intézet

${ }^{3}$ ELTE PPK Neveléstudományi Intézet

\title{
A reflektív naplók alkalmazásának lehetőségei a tanárképzésben
}

A reflektív gondolkodás elengedhetetlen kelléke a tanárok szakmai repertoárjának, igy a 20. század végétól a reflektivitás egyre nagyobb hangsúlyt kap a pedagógusképzésben (Kinsella, 2007; Collin, Karsenti és Komis, 2013). Jelen tanulmány a reflektív naplónak mint a reflektivitás egyik hatékony eszközének tanárképzésben való alkalmazási lehetôségeit tárja fel a szakirodalmi elemzés módszerével. A kutatásba bevont tanulmányok céljait és eredményeit vizsgálja a reflektív naplóírás tanárszakos hallgatók fejlódésére gyakorolt hatásainak relevanciájában. A reflektív naplókkal kapcsolatos kutatások eredményei rávilágítottak, hogy a naplóírás különbözó területen gyakorolhat hatást a tanárrá válás folyamatában. Támogathatja a szakmai tudás elmélyülését, tudatosabbá teheti a tanári gyakorlatot, de segitheti a tanitással kapcsolatos attitüdök, nézetek felülvizsgálatát is. Emellett fejlesztheti a tanárszakos hallgatók reflektivitásának szintjét és hozzájárulhat inkluziv szemléletmódjuk kialakitásához.

\section{Bevezetés}

S zámos kutatás alátámasztja, hogy a reflektív gondolkodás és az ehhez szükséges készségek kulcsfontosságúak ahhoz, hogy a pedagógusok képesek legyenek oktató-nevelő tevékenységük értelmezésére és ezáltal fejlesztésére (Darling-Hammond, 2006; Nolan és Sim, 2011; Szivák, 2014), és hogy a reflektív gondolkodás elméletének ismerete, illetve a hozzátartozó készségek fejlesztése jelentős szerepet játszik a pedagógusképzésben, hiszen ez a folyamat nagymértékben meghatározhatja a leendő pedagógusok későbbi, az oktatási intézményekben folytatott reflektív gyakorlatát (Stenberg, Rajala, és Hilppo, 2016). Amennyiben a pedagógushallgatók lehetőséget kapnak arra, hogy elsajátítsák a reflexió technikáját, és tanítási gyakorlatukra, illetve a tanulócsoportban történő folyamatokra reflektíven reagáljanak, képesek lesznek tudatosan részt venni saját fejlődési folyamatukban. Döntéseket fognak tudni meghozni, képesek lesznek tudatosan választani a tanult pedagógiai módszerek gyakorlati alkalmazását illetően, illetve későbbi pedagógiai gyakorlatukat elemezve a már meglévő ismereteiket és az újonnan tanultakat szintetizálni tudják egy adott probléma megoldása érdekében (Park, 2003; Mair, 2010; DeCapua, Marshall, és Frydland, 2018; Zhu, Iglesia és Wang, 2020). 


\section{A reflektív gondolkodásról}

A 20. század végétől a reflexió egyre nagyobb hangsúlyt kap a pedagógusképzésben (Kinsella, 2007; Collin, Karsenti és Komis, 2013). A tanítás-tanulás hagyományos felfogásmódja szerint a tanár egy „tudásbank bankára”, aki a tanulási folyamat alatt szétosztja a tudást a tanulók között. A tanulás folyamata, azaz a tudáselosztás a tanulók szemszögéből passzív, kizárólag a tanár személyéhez mint központi szereplőhöz kötődő, számszerüen mérhető folyamat (Freire, 2005). Ezzel szemben a konstruktivista felfogásmód szerint a tanulás egy dinamikusan változó folyamat, amelyben jelentős szerepe van a hallgatók előzetes tudásának. A tudás olyan konstrukciós mủvelet eredménye, amelyben szerepe van a reflexiónak, a kritikus gondolkodásnak, illetve a szociális közegben végbemenő interakcióknak és az ezekre adott válaszoknak (Good és Whang, 2002), tehát a tanulás is aktív és minőségi változókkal leírható folyamat.

A reflektív gondolkodás lehetővé teszi a pedagógushallgatók számára, hogy tudatosan részt vegyenek a saját tanulási folyamatukban azáltal, hogy tárgyilagosan elemzik tanítási tapasztalataikat, és az alapján változtathatnak tanítási módszereiken (Pollard, 2008). A reflektív gondolkodás Dewey koncepciójával jelenik meg a pedagógiában, aki ezt egy aktív, kitartó és mély megfontolásokkal teli gondolkodási folyamatnak tekintette, amelynek célja, hogy adott helyzetben felmerülö problémákra, helyzetre megfelelő megoldást, választ találjon (Hatton és Smith, 1995). Schön (1987) egy dinamikus hatás-ellenhatás folyamatként jellemzi a reflexiót, amelyben a pedagógus elméleti és praktikus tudását felhasználva keretbe foglalja a problémát kognitív struktúrák, sémák segítségével és többszöri átgondolás, értelmezés és elemzés során találja meg a legmegfelelőbb megoldást egy adott szituációban (Szivák, 2014).

Korthagen (2001) hangsúlyozza a reflexió jelenlétének fontosságát a tanárképzésben, mivel a reflektív gondolkodás segítheti a leendö tanárokat abban, hogy ne a korábbi tanulmányaik során berögzült tanítási minta alapján tanítsanak. A szisztematikus reflektív gondolkodás kapcsolatot teremt a reflektáló személy korábbi és jelenlegi tanítási tapasztalatai között, valamint összekapcsolja a saját és a reflexióban részt vevő egyéb személyek tudását (Shavit és Moshe, 2019). Ezáltal a pedagógusjelöltek szakmai fejlödésében hangsúlyos szerep jut a reflexiónak (Syslova, 2015), melynek során elsősorban a hallgatók szakmai tudatossága erősödik. A reflexió mint szakmai fejlődést támogató eszköz szerves részét képezheti a pedagógusképzésnek, hiszen ezen keresztül a hallgatók szembesülnek saját metakognitív folyamataikkal: a tanítással kapcsolatos attitüdjeikkel, hiedelmeikkel, felfogásmódjukkal és szakmai önképükkel (Collina és Karsentib, 2011). A reflexió folyamán a pedagógushallgatók szisztematikusan át tudják gondolni a pedagógusképzésben tanultakat, illetve az osztálytermi gyakorlatokban szerzett tapasztalataikat, megtalálhatják az elméleti ismeretek és a gyakorlati tapasztalatok közti kapcsolatot. Elméleti tudásuk tanítási gyakorlatukba való adaptálásakor a tanárszakos hallgatók képessé válhatnak arra, hogy a tanítási folyamatot egyre tudatosabban szemléljék, és felismerjék, hogy saját szakmai fejlödésükben milyen területekre kell még hangsúlyt fektetniük (Aldahmash, Alshmrani és Almufti, 2017).

\section{Reflektiv naplók a pedagógusképzésben}

Egy olyan tanítási folyamatban, amely a reflektív gondolkodási képesség fejlesztésére irányul, a tanuló aktív döntéshozóként, a tanár pedig segítöként és ösztönzőként vesz részt (Wilson és Jan, 1993). A reflektív tanulás során az értékelés folyamatorientált, a hallgató saját reflektivitásán és a konstruktív folyamatokon keresztül tanul, a tanár pedig értékeli a folyamatot, és segíti a hallgató hibáinak, hiányosságainak korrigálását. 
A reflexió tehát a tanulást folyamatos és tudatos fejlödési folyamattá teszi (Ersözlü és Arslan, 2009).

A reflektív gondolkodás fejlesztésére, támogatására többféle módszer is létezik. Ez a tanulmány a reflektív naplókra mint a reflexiót támogató írásos formák egyikére fókuszál. Számos szerző véleménye támasztja alá, hogy a reflektív napló az egyik leghatékonyabb módszer a reflektív gondolkodási készségek fejlesztésére (Bolin, 1988; Clift és Houston, 1990; Langer, 2002; Park, 2003; Kazu és Demiralp, 2012; Lowe, Prout és Murcia; 2013; Cengiz és Karataş, 2015). A reflektív napló olyan dokumentum, amely a tanítás tervezésével, előkészítésével és megvalósításával kapcsolatos tapasztalatokat és érzéseket tartalmazza (Scales, 2008). Lehetőséget ad írójának, hogy kronologikus sorrendben megörökítse a tanulással vagy tanítással kapcsolatos eseményeket, majd reflektáljon rájuk (Szivák, 2014). Alkalmazható egyrészt a tanulási folyamatban, amikor a hallgatók a tanórán elhangzottakra, a tananyagra, az alkalmazott módszerekre reflektálnak, illetve a tanítási folyamatban is, amikor a hallgatók, vagy akár a gyakorló tanárok saját tanítási gyakorlatukra reflektálnak (Porter, Goldstein, Leatherman és Conrad, 1990; Good és Whang, 2002).

A reflektív naplók számos formája jelen van a tanárképzésben. A dialogikus reflektív naplókban a reflexió párbeszédes formában történik, általában tanár-tanuló vagy tanuló-tanuló interakciók révén valósul meg. A résztvevők a párbeszédekben tapasztalataikat, véleményeiket osztják meg egymással abból a célból, hogy a folyamatban fejlödjön a tanuló önbizalma, illetve az önálló tanulása, és képes legyen összekapcsolni az elméleti órán tanultakat és a tanítási gyakorlatában tapasztaltakat (Porter, Goldstein, Leatherman és Conrad, 1990). A válasznaplók a hallgatók személyes reakcióit, kérdéseit és gondolatait tartalmazzák mindarról, amit tanulmányaik alatt olvasnak, írnak, tanulnak, megfigyelnek, illetve ahogyan cselekednek. A tanítási naplóknak hasonló a céljuk, de ezek kifejezetten a tanítási szituációra íródnak, azokat a helyzeteket dolgozzák fel, amelyekkel a tanárszakos hallgatók tanítási gyakorlatuk idején találkoztak (Lee, 2008).

Hatton és Smith (1995) szerint ahhoz, hogy a reflexiós gyakorlat a tanárképzésben elmélyíthető legyen, szükség van bizonyos feltételekre. Véleményük szerint a tanárszakos hallgatóknak lehetőséget kell adni, hogy megalkothassák saját elképzelésüket a
A reflektív naplók számos formája jelen van a tanárképzésben. A dialogikus reflektí naplókban a reflexió párbeszédes formában történik, általában tanár-tanuló vagy tanuló-tanuló interakciók révén valósul meg. A résztvevók a párbeszédekben tapasztalataikat, véleményeiket osztják meg egymással abból a célból, hogy a folyamatban fejlódjön a tanuló önbizalma, illetve az önálló tanulása, és képes legyen összekapcsolni az elméleti órán tanultakat és a tanitási gyakorlatában tapasztaltakat (Porter, Goldstein, Leatherman és Conrad, 1990). A válasznaplók a hallgatók személyes reakcióit, kérdéseit és gondolatait tartalmazzák mindarról, amit tanulmányaik alatt olvasnak, irnak, tanulnak, megfigyelnek, illetve ahogyan cselekednek. A tanitási naplóknak hasonló a céljuk, de ezek kifejezetten a tanítási szi-

tuációra iródnak, azokat a helyzeteket dolgozzák fel, amelyekkel a tanárszakos hallgatók tanítási gyakorlatuk idején találkoztak (Lee, 2008). 
tanításról, együttmüködő, biztonságos környezetben fedezhessék fel a tanítás gyakorlatát, képessé váljanak arra, hogy felismerjék a tanítás gyakorlatának problémáit, megismerjék a módszerek és azok alkalmazásának sokféleségét, és felépíthessék saját képességeik repertoárját. A reflektív naplóírás gyakorlatában ezek a feltételek megvalósulnak, hiszen a naplóírás során a hallgatók „hallathatják egyéni hangjukat, ezt megoszthatják kurzustársaikkal és oktatóikkal, ezáltal hatással lehetnek egymás szakmai fejlődésére" (Good és Whang, 2002).

A kutatások a reflektív naplók tanárszakos hallgatók tanításában való alkalmazásának további számos előnyös hatására rámutattak. A reflektív napló vezetésekor a hallgatók jegyzeteket készíthetnek arról, hogy mit és hogyan tanultak a kurzuson, és milyen érzéseik vannak a folyamattal kapcsolatosan (Garmon, 1998). A reflektív napló lehetővé teszi a hallgatók számára, hogy autonómmá váljanak a tanulás során (Good és Whang, 2002), lehetőséget adhat számukra egyfajta kritikai reflexióra azáltal, hogy összegyüjtik az érzéseiket, tapasztalataikat, frusztrációikat a megvalósult tanítási folyamattal kapcsolatban (Farrell, 2006). Segíthet abban is, hogy a hallgatók sajátos, egyéni kontextusuknak megfelelö megoldásokat alkalmazzanak a különbözö helyzetekben (Bean és Zulich, 1989). Az angol mint idegen nyelv tanításakor pedig az angolul megírt naplók a nyelvi tudás fejlődését is elösegítik (Tuan, 2010).

\section{A szakirodalmi feltárás lépései}

Jelen tanulmány a reflektív naplónak mint a reflektivitás egyik hatékony eszközének tanárképzésben való alkalmazási lehetőségeit tárja fel a szakirodalmi elemzés módszerével (Gough, Oliver és Thomas, 2012). Az irodalmi elemzés alapját a Preferred Items for Systematic Reviews and MetaAnalysis (PRISMA) ellenőrzőlista elemei adták (Moher, Liberati, Tetzlaff és Altman, 2009). Az elemzés a következő lépések mentén valósult meg: (1) a releváns tanulmányok befogadási, illetve kizárási kritériumainak meghatározása, (2) a tanulmányok keresési stratégiájának meghatározása, (3) a kutatásba bevonható tanulmányok azonosítása szüréssel (4) a kutatásba bevont tanulmányok feldolgozása és értékelése, (5) a kutatásba bevont tanulmányok elemzése és összefoglalása. Az elemzésbe beválogatott tanulmányok megfelelési kritériumait az 1. ábra foglalja össze.

\begin{tabular}{|r|l|}
\hline a kutatás populációja & - tanárszakos hallgatók \\
a kutatás témája, fókuszpontjai & - reflektív naplók \\
& - tanárképzés \\
& - azok a tanulmányok, amelyek a reflektív naplók tanár- \\
& képzésben való alkalmazásának hatását, eredményeit \\
& vizsgálták \\
a kutatás típusa & - empirikus kutatások, amelyek egyértelműen leírják az \\
& elméleti hátteret, a módszertant és a kutatás során kapott \\
& adatokat, amelyekre a következtetéseiket alapozzák \\
a kutatás módszere & - kvalitatív, kvantitatív és vegyes módszer \\
a tanulmány jellemzöi & - angol nyelven íródott \\
& -1994 és 2020 között publikálták \\
& - teljes szövege elérhetö \\
\hline
\end{tabular}

1. ábra. Megfelelési kritériumok 
Miután meghatároztuk a megfelelési kritériumokat és a keresési stratégiát, a következő lépés a tanulmányok felkutatása volt. A kutatást két elektronikus adatbázis, az Ebsco és a Web Of Science használatával végeztük. Mindkét adatbázisban egyszerü kulcsszavas keresést alkalmaztunk, a következő keresőkifejezésekkel: a reflektív naplókra a reflective journals kifejezéssel kerestünk, míg a tanárszakos hallgatók kifejezésre a preservice teachers, teacher students és teacher education kulcsszavakat használtuk. A kifejezéseket az AND kötőszóval kapcsoltuk össze. Ezt követte a tanulmányok lekérdezése és rögzítése, majd a cikkek szürése különböző feltételek mentén (ld. 2. ábra). A két adatbázisban a kulcsszavas keresés eredményeként 1850 tanulmányt találtunk. A duplikátumok eltávolítása után a tanulmányok címének és absztraktjának vizsgálata következett. A vizsgálat alapján kizártunk 1327 tanulmányt, azokat, amelyek nem az általunk meghatározott témára fókuszáltak. A vizsgálat következö lépésében a megmaradt 37 tanulmányt dolgoztuk fel. Ezeket a teljes szöveg feldolgozásával értékeltünk a megfelelési kritériumok mentén. Az elemzésbe végül az a 15 tanulmány került, amely minden szempontból megfelelt az összeállított szempontrendszernek.

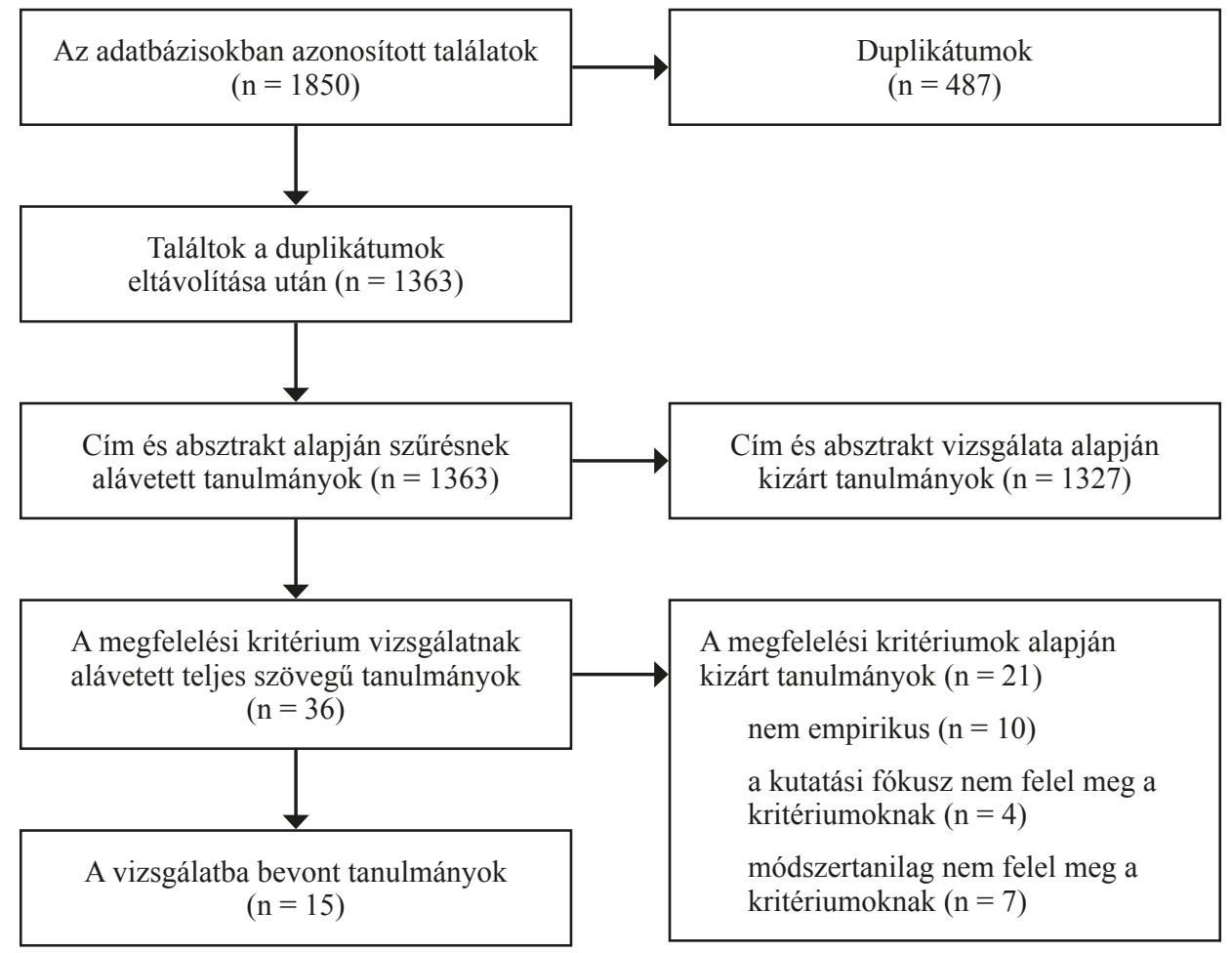

2. ábra. A vizsgálatba bevont tanulmányok kiválasztását bemutató PRISMA folyamatábra 


\section{A vizsgálatban szereplö tanulmányok}

A vizsgálatba bevont tanulmányok feldolgozásából származó információkat táblázatban rögzítettük. Az elemzés folyamán különös hangsúlyt fektettünk a kutatási módszerek és eredmények részletes feldolgozására, hiszen a reflektív naplók tanárképzésben való alkalmazhatósága elsősorban ezekben az adatokban mutatkozott meg.

A feldolgozott kutatások mindegyike kis elemszámú, kvalitatív kutatás volt, amelyek elsősorban a reflektív naplók tartalomelemzését végezték el különböző célokból és különböző szempontok alapján. A kutatásokban szereplő reflektív naplók a válasznapló (50\%) és a tanítási napló (40\%) kategóriába estek, de volt két kutatás, amely dialogikus napló elemzését végezte el.

Az elemzett tanulmányok mindegyike a tartalomelemzés módszerét használta a naplóbejegyzések feltárására, egy tanulmány alkalmazott kvantitatív adatelemzést is.

A naplók elemzésének célja az egyes tanulmányokban eltérő volt, azonban találtunk olyan visszatérő mintázatokat, amelyek alapján a következő csoportokat tudtuk alkotni:

- a reflexivitás szintjeinek és ezek változásának vizsgálata a tanárszakos hallgatók reflektív naplóiban,

- a reflektív napló alkalmazásának hatása a hallgatók tanítási gyakorlatára,

- a reflektív naplók alkalmazása a hallgatók attitüdjének, nézeteinek formálásában.

\section{Reflektív naplók a tanárrá válás folyamatában}

\section{A reflektív napló mint a hallgatók reflektivitásának szintjeit feltáró eszköz}

A tanárszakos hallgatók reflektív naplóit elemző kutatások egyik célja az, hogy feltárják a hallgatók reflektív naplóbejegyzéseiben a reflektivitási szinteket, illetve azt, hogy a naplóírás folyamán a hallgatók reflektivitási szintjében történik-e változás (Alger, 2006; Lee, 2008; Cohen-Sayag és Fischl, 2012; Arrastia, Rawls, Brinkerhoff és Roehrig, 2014; Nurfaidah, Lengkanawati és Sukyadi, 2017; Tuncer és Ozkan, 2018).

A reflektivitás szintjeinek vizsgálata általában egy bizonyos modell vagy szempontrendszer alapján történik. Mivel számos, a reflektivitás szintjeit leíró modell létezik, így a különböző kutatások eltérő modelleket alkalmaznak. A következőkben azokat a modelleket tekintjük át, amelyek a vizsgált kutatásokban megjelentek.

\section{A reflektivitás szintjei}

A reflektivitás szintjeinek első kategóriarendszerét Van Manen alkotta 1977-ben. Három szintjét különböztette meg a reflektivitásnak: technikai, gyakorlati/tartalmi és dialektikus szint. A technikai szint kontextus nélküli általánosításokat és egyszerü elméleti leírásokat tartalmaz (Nurfaidah, Lengkanawati és Sukyadi, 2017). A tartalmi szint az osztálytermi gyakorlatok során felhalmozott tapasztalatok, problémák, a tanulói sajátosságok tükrében tekint az oktatásra. A dialektikus szint pedig egy multikontextuális dimenzió, amelyben a pedagógusok az osztálytermi gyakorlatok folyamatait tágabb összefüggésben szemlélik, fontolóra veszik a politikai, etikai, társadalmi kapcsolódásokat (Szivák, 2014). Van Manen kategóriáit számos kutatás vette alapul, illetve fejlesztette tovább. Hatton és Smith 1994-ben egy négyszintü kategóriarendszert mutat be (ld. 3.ábra), amely bemutatja a reflexió különböző típusait: leírás, leíró reflexió, dialogikus reflexió és kritikai reflexió. 


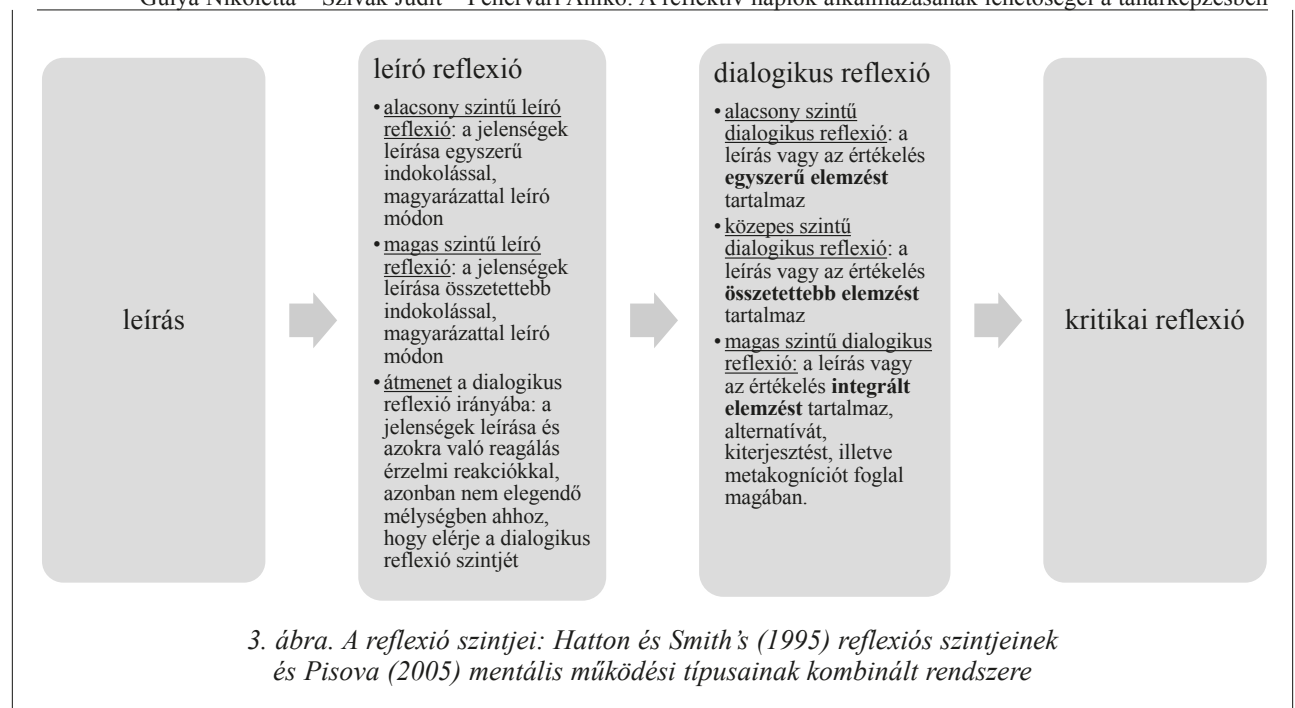

Ezt a kategóriarendszert Nurfaidah, Lengkanawati és Sukyadi 2017-ben továbbfejlesztette, mert kutatásuk során nem bizonyult elég részletesnek. A négy kategóriát további alkategóriákra bontották Pysova (2005, idézi Syslova 2015) a reflexió során fellelhető mentális tevékenységi típusokat leíró modelljének segítségével. Pysova (2005, idézi Syslova, 2015) modelljében hat olyan mentális tevékenységtípust ír le, amelyek elöfordulhatnak a reflexió során. Syslova (2015) szerint ezek a mentális tevékenységtípusok a reflexió különböző szintjeire jellemzőek, így jól beilleszthetőek Korthagen és Vasalos (2005) a reflexió folyamatának szintjeiről alkotott modelljébe (ALACT model) (ld. 4. ábra). Nurfaidah, Lengkanawati és Sukyadi (2017) ezeknek a modelleknek a szintéziséből hozta létre a reflexiós szintek részletesebb elemzését lehetővé tevő kategóriarendszerét (ld. 3. ábra), amely a következő szinteket tartalmazza: (1) A legalsó szint a leírás, amely nem tekinthető reflexiónak. A leírás felsorolásszerü, összegyüjti a tanteremben történt eseményeket, mindenféle magyarázat vagy elemzés nélkül. Tehát ezen a szinten a hallgatók csak leírják, hogy mi történt, de nem füznek hozzá megjegyzéseket, magyarázatokat, azaz nem reflektálnak a megtörtént eseményekre. Számos tanárszakos hallgató alkalmazza a leírást reflektív gyakorlatának kezdetén (Nurfaidah, Lengkanawati és Sukyadi, 2017). A következő szint a leíró reflexió, amely már tartalmaz reagálásokat, magyarázatokat, azonban kizárólag a felsorolás, leírás szintjén. Ezt a kategóriát Pysova (2005) mentális tevékenységtípusai alapján további három szintre bontották (ld. 3. ábra). Az értékelés alapja itt a reflexió szintje, az egyre magasabb szinteken a reflexió indoklásai, magyarázatai is egyre komplexebekké válnak. A következő szint a dialogikus reflexió szintje. 


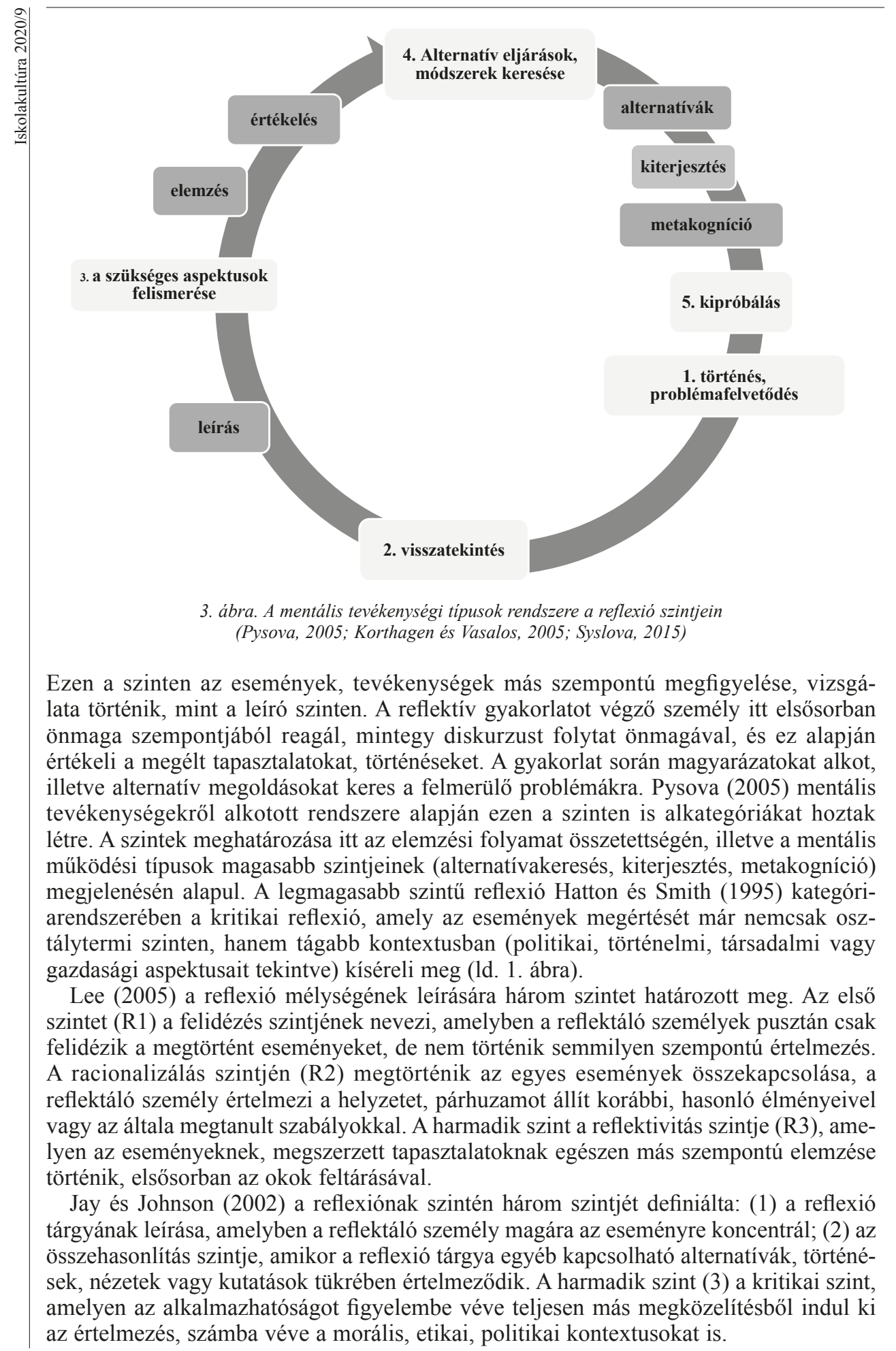


Ward és McCotter 2004-ben értékelő kereszttáblát hozott létre, amely a reflexió értékelésének három dimenzióját (fókusz, a vizsgálat iránya és változás), illetve négy szintjét (rutin, technikai, dialogikus és átalakító) határozta meg. A rubrik elkészítéséhez két adatállomány (a Renaissance Teacher Work Sample és a Collaborative Inquiry: Reflection, Questions about Student Learning) adatait használták fel, amelyek a tanárszakos hallgatók reflexióit foglalják magukba. A felmérés során a tanárszakos hallgatók 15-20 oldalas reflektív elemzést írnak a tanítási gyakorlatukról, Ward és McCotter ezt elemezve készítette el reflexiót értékelő kereszttábláját (ld. 4. ábra).

\begin{tabular}{|c|c|c|c|c|}
\hline \multirow[t]{3}{*}{ Dimenziók } & & & & \\
\hline & \multicolumn{4}{|l|}{ Szintek } \\
\hline & $\begin{array}{l}\text { Rutin } \\
\text { nem eredményez } \\
\text { változást }\end{array}$ & $\begin{array}{l}\text { Technikai } \\
\text { a felmerült helyzet } \\
\text { megoldására fizikai } \\
\text { eszközöket keres, } \\
\text { nincs perspektíva- } \\
\text { váltás }\end{array}$ & $\begin{array}{l}\text { Dialogikus } \\
\text { a helyzetmegoldás } \\
\text { során felmerülnek új } \\
\text { alternatívák, illetve } \\
\text { más személyek } \\
\text { megközelítéseit is } \\
\text { figyelembe veszi }\end{array}$ & $\begin{array}{l}\text { Átalakító } \\
\text { alapvető kérdésekben } \\
\text { történő változás }\end{array}$ \\
\hline $\begin{array}{l}\text { Fókusz } \\
\text { Kire vagy mire } \\
\text { irányul a figyelem } \\
\text { a tevékenység kap- } \\
\text { csán? }\end{array}$ & önmaga & $\begin{array}{l}\text { az oktatási feladatok, } \\
\text { tevékenységek }\end{array}$ & a tanulók & $\begin{array}{l}\text { a személyes rész- } \\
\text { vétel, az alapvető } \\
\text { pedagógiai, etikai, } \\
\text { erkölcsi, kulturális } \\
\text { vagy történelmi } \\
\text { kontextus figyelembe } \\
\text { vételével }\end{array}$ \\
\hline $\begin{array}{l}\text { A vizsgálat iránya } \\
\text { Kire vagy mire } \\
\text { irányulnak a reflexió } \\
\text { kérdései? }\end{array}$ & $\begin{array}{l}\text { személyes változásra } \\
\text { irányuló kérdések } \\
\text { nincsenek, az okokat } \\
\text { külső, gátló ténye- } \\
\text { zőkben keresi (kevés } \\
\text { idő, kevés fizetés) }\end{array}$ & $\begin{array}{l}\text { a specifikus hely- } \\
\text { zetek (meglepő } \\
\text { eredmények, fruszt- } \\
\text { rációk) elemzésére } \\
\text { irányuló kérdések }\end{array}$ & $\begin{array}{l}\text { a helyzetből adódóan } \\
\text { új kérdések merülnek } \\
\text { fel, amelyek más } \\
\text { személyekkel együtt } \\
\text { közös gondolkodásra } \\
\text { ösztönöznek (nyitott } \\
\text { mások véleményére) }\end{array}$ & $\begin{array}{l}\text { hosszútávú érdek- } \\
\text { lődés, és együttmü- } \\
\text { ködés mentorral, } \\
\text { társakkal, kritikai } \\
\text { szemléletü kérdések, } \\
\text { amelyek a személyi- } \\
\text { ség megváltoztatásá- } \\
\text { ra ösztönöznek }\end{array}$ \\
\hline $\begin{array}{l}\text { Változás } \\
\text { A vizsgálat folya- } \\
\text { mata milyen válto- } \\
\text { zásokat indukál a } \\
\text { személyiségben és a } \\
\text { felfogásmódban? }\end{array}$ & $\begin{array}{l}\text { a tanítási gyakorlat } \\
\text { elemzése, a szemé- } \\
\text { lyes tényezők figye- } \\
\text { lembevétele nélkül- } \\
\text { mintha a személyes } \\
\text { tényező nem lenne a } \\
\text { folyamat része }\end{array}$ & $\begin{array}{l}\text { személyes válaszok } \\
\text { a helyzetre, de a } \\
\text { helyzetelemzés nem } \\
\text { vezet szemléletvál- } \\
\text { táshoz }\end{array}$ & $\begin{array}{l}\text { a személyes erős- } \\
\text { ségek-gyengeségek } \\
\text { felismerése változá- } \\
\text { sokat okoz, és fejlő- } \\
\text { dik a tanári gyakorlat }\end{array}$ & $\begin{array}{l}\text { teljesen új szemlé- } \\
\text { letmód kialakulása, } \\
\text { amely nagymérték- } \\
\text { ben megváltoztatja a } \\
\text { tanári gyakorlatot }\end{array}$ \\
\hline
\end{tabular}

4. ábra. Ward és McCotter (2004) reflexiót értékelö rubrikja

\section{A reflektivitás szintjeit vizsgáló tanulmányok tanulságai}

Tuncer és Ozkan (2018) 10 tanárszakos hallgató tanítási reflexióit elemezte, amelyeket egy 12 héten át tartó tanítási gyakorlat kurzus során írtak. A kurzust megelőzte egy bevezető kurzus, amelyen a kutatók informálták a hallgatókat arról, hogy hogyan kell reflektív naplót írni. Ezután a kutatók arra kérték a hallgatókat, hogy szabadon reflektáljanak a gyakorlatukra a 12 hét alatt. A 2. héten a kutatók a reflektív naplók elemzése során azt tapasztalták, hogy a hallgatók nagy része csak leírta az aktuális napon történt eseményeket, de nem néztek mélyebben a történtek mögé, nem elemezték annak okait 
és következményeit. Ezért úgy döntöttek, hogy készítenek egy listát, amellyel segítik elmélyíteni a hallgatók elméleti ismereteit a reflektív írásról. Ezután a beavatkozás után egyéb segítséget már nem nyújtottak a hallgatóknak. A reflektivitás szintjeinek meghatározása ebben a kutatásban Lee (2005) modellje alapján történt. A kutatás eredményei rávilágítottak, hogy a hallgatók nagy része a kurzus végeztével is a felidézési szinten (R1) reflektált, azaz a hallgatók felidézték és felsorolták a tanítási gyakorlatuk eseményeit, de ezek értelmezése elmaradt. Néhány hallgatónál azonban a kurzus utolsó két hetében változás volt tapasztalható, elmozdulás történt a racionalizálás (R2), illetve a reflektivitási (R3) szintek felé.

Ekkor a hallgatók már az események mögött húzódó okok feltárására, azok összekapcsolására is kísérletet tettek, illetve feltárták az alternatív lehetőségeket is bizonyos tanítási helyzetekkel kapcsolatban.

Nurfaidah, Lengkanawati és Sukyadi (2017) négy pedagógushallgató tanítási gyakorlata során készített tanítási naplójának tartalomelemzését végezte el a reflektivitás szintjeinek szempontjából. A kutatásban részt vevő hallgatók mindegyikének ez volt az első alkalom, hogy valós oktatási helyzetben kipróbálhatta magát. Ezt megelőzően mikrotanítás kurzust végeztek, amelynek a reflektív gyakorlat is részét képezte. A hallgatók a naplóírást egy Richards és Lockhart (1996) által összeállított útmutató szerint végezték. A hallgatók reflektív naplóikat e-mailben küldték el a kutatóknak heti rendszerességgel. Kutatásuk alapjául a Hatton és Smith 1995-ben létrehozott és Pysova által 2005-ben kiegészített reflektivitási kategóriarendszer szolgált (ld. 1. ábra). Eredményeik azt mutatják, hogy a tanárszakos hallgatók 1 szemeszter alatt nem mutatnak jelentős fejlődést a reflektivitás szintjeit illetően. Az általuk vizsgált hallgatók nagy része a dialogikus szint alacsony és közepes kategóriájáig jutott a reflexió során, és a naplóik elsősorban oktatási gyakorlatuk leírását, elemzését és értékelését tartalmazták. Bár egy bizonyos szintű fejlődés itt is detektálható volt, a hallgatók egy szemeszter alatt nem jutottak el a reflektivitás kritikai szintjére.

Arrastia, Rawls, Brinkerhoff és Roehrig (2014) 90 tanárszakos hallgató reflektív naplóinak tartalomelemzését végezte el. Ez a kutatás a tartalomelemzés kódrendszeréül Ward és McCotter (2004) a reflektivitás szintjeinek vizsgálatára összeállított kereszttábláját (ld. 3. ábra) alkalmazta. A kutatás eredményei rávilágít, hogy a szemeszter végére a hallgatók 10\%-ának reflektivitási szintjében nem történt változás, 35\%-nak azonban emelkedett a reflektivitási szintje. Hasonló eredményekről számol be Alger (2006) és Lee (2008) is. Ezekben a kutatásokban tehát az időtényező az, ami meghatározó a reflektív gondolkodás kialakítása szempontjából.

Az időtényező mellett azonban egyéb tényezők is befolyással lehetnek a reflektivitás szintjének fejlödésére. Cohen-Sayag és Fischl (2012) két különböző csoporton (A csoport $\mathrm{n}=15, \mathrm{~B}$ csoport $\mathrm{n}=9$ ) kutatta a reflektivitás szintjének változását. A két csoport közötti lényeges eltérés a hallgatók reflektív naplóit értékelő oktatói visszajelzésekben feltárt különbség volt. Az A csoport csak megerősítő visszajelzéseket kapott az oktatójától (nem volt benne kritika, csak nyugtázta, hogy elvégezték a feladatot), a B csoport pedig olyan visszajelzéseket kapott, amelyben az oktató magasabb reflexiós szinten való megnyilvánulásra ösztönözte hallgatóit. A kutatásban a reflektivitás szintjeit Jay és Johnson (2002) kategóriarendszere alapján értékelték. Az eredmények azt mutatják, hogy az A csoportban lévő hallgatók megmaradtak az első szinten, zömében magukra koncentráltak, és leíró formában csak összegezték az eseményeket. A B csoportban lévő tanulók azonban elmozdultak a reflektivitás 2 . és 3. szintje felé, összehasonlítottak, illetve már a kritikai szintet is elérték. A kutatás kvantitatív számításokat is végzett, amelyek mindezeket számadatokkal is alátámasztják. Eszerint a szemeszter elején mindkét csoport esetében a leíró szint volt a jellemző. A szemeszter végén az A csoportban hasonlóak maradtak az adatok, míg a B csoportban emelkedett az összehasonlító, illetve a kritikai szint aránya. 
Az elemzett kutatások tehát két fö, a hallgatók reflexiós szintjeit befolyásoló tényezőt tártak fel. Az egyik az időtényező, amely összefüggésében elmondható, hogy a reflexió elsajátítása időigényes folyamat, a hallgatók nagy részének több mint 1 szemeszterre van ahhoz szükség, hogy reflektivitási szintet lépjenek. A másik fontos tényező pedig az oktatók visszajelzése a hallgatók munkájára. Ezek akkor bizonyulnak hatékonynak, amennyiben ösztönzik a hallgatókat arra, hogy a reflexió magasabb szintjein is megnyilvánuljanak.

\section{A reflektív naplóírás hatása} a hallgatók szakmai fejlödésére

A reflektív gyakorlat segíti a tanárszakos hallgatókat és a gyakorló tanárokat is, hogy tudatosabbá váljanak tanítási gyakorlatuk kapcsán azáltal, hogy folyamatosan figyelik és reflektálnak az általuk végzett tanítási folyamatra (Thompson és Pascal, 2012). A tanítási gyakorlat, a tanítással kapcsolatos eszközök feltárása a reflektív naplóíráson keresztül is megvalósítható. Számos kutatás vizsgálta a reflektív naplóírás tanárszakos hallgatók szakmai fejlődésére, tanítási gyakorlatára, tanítással kapcsolatos attitüdjeire gyakorolt hatását (Angela és Feng, 1994; Good és Whang, 2002; Maarof, 2007; Cengiz és Karataş, 2015; Kim, 2018; Zulfikar és Mujiburrahman, 2018).

Angela és Feng (1994) áttekintő elemzése azt vizsgálta, hogy a reflektív naplóírás hogyan segíti a hatékony tanítás jellemzöinek tudatosítását a tanítás folyamatában. A naplóírás segítségével felfedhetők a tanítási gyakorlat erősségei és gyengéi, így a reflektáló személy össze tudja gyüjteni azokat a tanítási stratégiákat és módszereket, amelyek a reflexiói alapján hatásosnak bizonyulnak a tanítási folyamat során.

Good és Whang 2002-ben 47 tanárszakos hallgató válasznapló (respond journal) bejegyzéseit vizsgálta meg. A hallgatók oktatáspszichológia kurzuson kapták azt a feladatot, hogy írjanak reflektív naplót a kurzushoz tartozó olvasmányaikról, gondolataikról és magáról a kurzusról is. A naplóíráshoz kaptak egy leírást, illetve egy listát, amelyen segítő kérdések voltak. Minden hallgató választhatott magának egy reflektáló társat, akivel egymás naplóbejegyzéseit
Az idótényezó mellett azonban egyéb tényezók is befolyással lehetnek a reflektivitás szintjének fejlódésére. Cohen-Sayag és Fischl (2012) két különbözó csoporton ( $A$ csoport $n=15, B$ csoport $n=9)$ kutatta a reflektivitás szintjének változását. A két csoport közötti lényeges eltérés a hallgatók reflektív naplóit értékelō oktatói visszajelzések-

ben feltárt különbség volt. Az A csoport csak megerósító visszajelzéseket kapott az oktatójától (nem volt benne kritika, csak nyugtázta, hogy elvégezték a feladatot), a B csoport pedig olyan visszajelzéseket kapott, amelyben az oktató magasabb reflexiós szinten való megnyilvánulásra ösztönözte hallgatóit. A kutatásban a reflektivitás szintjeit Jay és Johnson (2002) kategóriarendszere alapján értékelték. Az eredmények azt mutatják, hogy az A csoportban lévó hallgatók megmaradtak az elsó szinten, zömében magukra koncentráltak, és leíró formában csak összegezték az eseményeket. A B csoportban lévó tanulók azonban elmozdultak a reflektivitás 2. és 3. szintje felé, összehasonlitottak, illetve már a kritikai szintet is elérték. 
véleményezték. A reflektív naplóírásról a hallgatóknak előzetes ismereteik alapján az alábbi véleményük volt: (1) fejleszti a gondolkodási képességeket, (2) demonstrálja és figyelemmel kíséri az előrehaladást, (3) lehetőséget kínál a múltbeli személyes események összekapcsolására a jövőbeli fejlesztéssel (reflexióval), és (4) lehetőséget ad az önértékeléshez. A hallgatók a szemeszter végén szintén leírták a véleményüket, tapasztalataikat a reflektív napló vezetéséröl. Ekkor négy téma köré fókuszálódott a véleményük: A reflektív napló vezetése (1) segített a gondolataikat fókuszálni, (2) segített tudásukat konkrétabbá tenni, (3) segített gondolataik elmélyítésében és a jelentésalkotásban, (4) segíteni fogja őket későbbi pályájukon mint egy visszatekintési lehetőség. A hallgatók azt is leírták, hogy a reflektív napló vezetését az előbbiekben felsorolt előnyei miatt valószínűleg gyakorló tanárként is alkalmazni fogják. Ebben a kutatásban a jelen gyakorlatainak elemzésén túl megjelenik a jövőorientált gondolkodás is, tehát a reflektív naplóírás a hallgatók jövőbeni tanári gyakorlatára is hatással lehet.

Maarof (2007) 42 hallgató írásait elemezve arra a megállapításra jutott, hogy a reflektív napló alkalmazása a tanárképzésben tudatosabbá teszi a hallgatókat mind a tanulási, mind a tanítási gyakorlatuk során. A hallgatók naplóinak elemzéséből kiderült, hogy a naplóírás segítette őket a tanítási módszerek értékelésében, határozottabbá tette őket az eszköz és módszerválasztásban azáltal, hogy felismerték azok erösségeit és gyengéit az alkalmazás utáni reflektálás folyamán.

Kim (2018) a tanárszakos hallgatók reflektív naplóinak fókusztémáit vizsgálva négy területet - (1) tanítás, (2) önmaga, (3) szakmai kérdések, (4) osztály tanulói - talált. A négy terület közül kiemelkedő volt a tanításra és a reflektáló személy önmagára való fókuszálása. A naplóbejegyzésekből kiderül, hogy a reflektív gyakorlatnak számos pozitív hatása van, tudatosabbá teszi a hallgatókat a saját tudás és tapasztalat összekapcsolásában, segíti a saját nézetek megerősödését a megszerzett tudás alkalmazási területeivel kapcsolatban.

Zulfikar és Mujiburrahman (2018) tanulmánya a tanárszakos hallgatók reflektív naplóírásról alkotott véleményét vizsgálta, illetve azt, hogy a naplóírás gyakorlata hogyan járul hozzá szakmai fejlődésükhöz. A hallgatók mindegyike szakmai fejlődést segítő hatékony eszközként tekintett a reflektív naplóírásra, azonban a reflektív naplóírásról alkotott nézeteikben különbségek mutatkoztak. A hallgatók egy részének a naplóíás elsősorban abban segített, hogy a reflektivitást beépítse szakmai gyakorlatába, és ezzel segítse szakmai fejlödését. A hallgatók nagy része pedig elsősorban abban látta a reflektív naplóírás hatékonyságát, hogy a naplóírás által tudatosabbá vált a tanítási folyamata. A reflektív naplók tartalmában is voltak különbségek. A hallgatók egyik csoportja az (1) osztályteremben zajló folyamatokra koncentrált, mint a különböző tanulókról készített feljegyzések, a köztük lévő interakciók leírása, valamint mindazok az osztályteremben lezajlott történések, amelyeket a hallgatók egyénileg érdekesnek találtak. A tanulók másik csoportja (2) saját tanítási folyamatára fókuszált, feljegyzéseik elsősorban a tanításhoz füződő nehézségeikhez, illetve nézeteikhez kapcsolódtak. A reflektáló hallgatók kis mértékben tértek csak ki (3) tanítási módszereikre, illetve az osztályteremben zajló (4) tanár-diák interakciókra. A hallgatók reflexiói szerint a naplóírás három fő célterület fejlesztésében volt a leghatékonyabb: (a) az osztálytermi gyakorlat, (b) az osztálytermi interakciók megfigyelése és megértése, (c) tanítási eszközök, módszerek kiválasztása. 
reflexiós gyakorlat

reflektív gyakorlat a tanítási folyamatban

önértékelés

szakmai

fejlődés

tanítási gyakorlat

eszközök, módszerek

osztálytermi interakciók

saját tudás és tapasztalat

összekapcsolása

hatékony tanítási

módszerek, stratégiák tanítással

kapcsolatos

attitüdök

nézetek, hiedelmek

nehézségek

jövőorientáltság

5. ábra. A reflektivitás tanárszakos hallgatók szakmai fejlödésére gyakorolt elemei

Az elemzett tanulmányok mindegyike hangsúlyozza, hogy a tanárszakos hallgatók fontos eszközként tekintenek a reflektív naplóírásra tanárrá válásuk folyamatában. Szakmai fejlődésüket a reflektív naplóírás három területen segíti elő hatékonyan (ld. 5. ábra): tanítási gyakorlatukban, reflexiós gyakorlatukban és a tanítással kapcsolatos attitüdjeik feltárásában, illetve megváltoztatásában. A különbözö kutatások elemzésekor a részterületek leírásában, illetve megfogalmazásában találtunk különbségeket, azonban az elemek mindegyik kutatásban egyértelmüen beazonosíthatók voltak.

\section{A reflektív naplók alkalmazása a hallgatók társadalmi sokszinüséggel kapcsolatos attitüdjének, nézeteinek formálásában}

Napjainkban az osztálytermekben jelenlévő tanulók szociokulturális és képességbeli sokszínüsége vitathatatlan. Ez a tendencia megmutatkozik az oktatás minden szintjén. A társadalmi sokszínűség számos olyan módszert, gyakorlatot igényel, amellyel a tanár az osztályában lévő minden tanuló számára ideális körülményeket tud teremteni tanulmányi teljesítményének fokozására. A tanárszakos hallgatók elméleti és gyakorlati tudásrepertoárjában szükségszerüen jelen kell lennie a sokszínüség elfogadására és kezelésére alkalmas eszközöknek. Ladson-Billings (1995) szerint a kulturális szempontból érzékeny pedagógia módszertanának alkalmazása segíti a tanulók fejlödését intellektuális, szociális, érzelmi és politikai szempontból azáltal, hogy a tanár kulturális példákon keresztül valósítja meg a tudásátadást, a készségfejlesztést és az attitüdformálást. Ez a megközelítés lehetőséget teremt, hogy a tanulók összekapcsolják az otthonról hozott és az iskolában tanult ismereteiket, ezáltal javulhat tanulmányi teljesítményük (Ladson-Billings, 2014). A módszer alkalmazásának feltétele, hogy maga a tanár is elfogadja és értékelje a társadalmi sokszínüséget (Lucas és Villegas, 2013), hiszen így válik képessé arra, hogy hitelessége által a tanulási folyamatot hatékonnyá és érthetővé tegye (Gay, 2013). 
Acquah, Szelei és Katz (2020) 83 tanárszakos hallgató reflektív naplóinak elemzését mutatja be. A kutatás egy olyan multikulturális közegben valósult meg, amelyben a pedagógus hallgatók egy Erasmus program keretében a világ számos országából származtak. A kutatásban részt vevő hallgatók egy kulturálisan érzékeny pedagógia kurzus során megismerkedtek a kulturális sokszínüségre adható pedagógiai válaszokkal, illetve azokkal a módszerekkel, amelyek alkalmazásával kulturálisan érzékeny tanárokká válhatnak. A kutatók azt vizsgálták, hogy ebben a multikulturális közegben a hallgatók felismerik és alkalmazzák-e a kurzuson tanultakat és azt, hogy ennek különböző aspektusait hogyan tudják majd beépíteni a leendő tanítási folyamatukba. A hallgatóknak elsősorban arra kellett reflektálniuk, hogy a kurzushoz kapcsolódó olvasmányokból és esettanulmányokból mit tanultak, és ezeket hogyan tudják majd alkalmazni jövőbeni tanári gyakorlatukban. A hallgatók a feldolgozott olvasmányokból és esettanulmányokból a következő pedagógiai aspektusokra reflektáltak a kulturálisan érzékeny pedagógia kapcsán: (1) a tanulók közötti kapcsolatépítés ösztönzése (megismerjék a világot társaik révén), (2) a különböző értékek és viselkedési formákról való tanítás (ezáltal elfogadóbbak lesznek), (3) támogató környezet megteremtése (szocializációs folyamatokhoz), (4) közösségépítés, (5) a tanulók tanulási folyamatban való részvételének ösztönzése, illetve (6) a gondolkodási képességek fejlesztése. A reflexiós naplók elemzése arra is rámutatott, hogy a tanulók közel fele ismerte csak fel azt, hogy a kurzus során konkrétan maguk is kulturálisan sokszínü környezetben voltak.

LaBelle és Belknap (2016) tanulmánya 183 tanárszakos hallgató véleményét és annak változását vizsgálta a tanítás és az esélyegyenlőség kapcsán. A hallgatók egy filozófia kurzuson vettek részt, és ennek keretein belül vezettek reflektív naplót, amelyben a tanítással kapcsolatos esélyegyenlőségi kérdésekre reflektáltak. A reflexiók elsősorban arra irányultak, hogy a jövőben, gyakorló pedagógusként hogyan fogják megvalósítani az igazságos, mindenki számára elérhető oktatást. Ezek közül két fókuszterület emelkedett ki, a méltányosság és az, hogy minden tanuló képes tanulni. A méltányosság témája, annak gyakorlati lehetőségei számos különböző formában jelentek meg a reflektív naplókban, ezeket jellemzőik alapján négy nagy témakör köré lehet csoportosítani. (1) Inkluzív oktatás, amely magába foglalja a képességek, illetve a társadalmi-gazdasági különbségek szerinti sokszínüséget és annak elfogadását, illetve a részvétel 
lehetőségeinek megteremtését. A méltányosság elősegítése a (2) kulturálisan érzékeny oktatás által, a (3) differenciált oktatás megvalósításával, illetve a (4) tanulók számára biztonságos tanulási légkör megteremtésével. A másik gyakran visszatérö téma a reflektív naplókban az volt, hogy a tanárjelöltek hisznek abban, hogy minden tanuló képes tanulni. A tanárjelöltek reflektív bejegyzései a társadalmi igazságosság kérdéskör köré tömörülnek, kihívásként tekintenek arra, hogy minden egyes tanulóból igyekeznek majd kihozni képességeinek maximumát. A bejegyzések arról is tanúskodtak, hogy a hallgatók nem hisznek abban, hogy egy alacsonyabb társadalmi státuszú tanuló csak alacsony színvonalú munkát képes végezni, és hatékonyan szeretnének tenni annak érdekében, hogy ez ne is következzen e.

Bentley-Williams és Morgan (2013) kutatásában a tanárképzésben használt reflektív naplóírás az az eszköz, amely a hallgatókat segíti abban, hogy saját megfigyeléseik, felismeréseik alapján képesek legyenek megérteni az osztálytermi sokszínüséget és azt, hogy leendő tanárként milyen teendőik vannak, illetve lesznek ezzel kapcsolatban. A kutatás célja az volt, hogy a reflektív napló szövegeinek elemzésével feltárják azokat a lehetséges útvonalakat, amelyek egyikét egy tanárszakos hallgatónak szükségszerúen be kell járnia ahhoz, hogy megértse a leendő inkluzív oktatói szerepét. A hallgatóknak a szemeszter során reflektív naplót kellett vezetniük olvasmányaikról, illetve közösségekben tett (fogyatékossággal élő gyerekeket oktató, támogató) látogatásaikról az inkluzív oktatás megadott szempontjai szerint.

A naplók elemzése öt fókuszterület köré koncentrálódott. Az első terület az önismereti fejlődés (1) témaköre volt, mely során a reflektív naplókban számos, érzelmekről tanúskodó bejegyzés született. A hallgatók nagy részére sokkolóan hatott a fogyatékossággal élő emberekkel való találkozás és annak a súlya, hogy a későbbiekben esetleg az ő osztályukban is lehet ilyen tanuló. Többségük a későbbiekben képes volt túllépni ezen a kezdeti nehézségen, és rádöbbent, hogy a befogadó oktatás nem gesztus, hanem lehetőség arra, hogy minden gyermek élhessen tanuláshoz való jogával, és ezt többségi társai körében tehesse. A hallgatók megfogalmazták, hogy egy elhivatott tanár (amilyenek ők lesznek) fel kell, hogy készüljön az osztálytermi diverzitásra, hogy minden gyerek tudja a közösségben tanuláshoz való jogát érvényesíteni. Az elöítéletek, téves elképzelések és etikus viselkedés (2) témakörében számottevő volt a hallgatók reflexióiban az az igény, hogy tanárként képesek legyenek tenni a társadalmi akadályok megszüntetésének elősegítésében, illetve az esélyegyenlötlenséggel járó gyakorlatok csökkentésében. Makroszintre emelve a kérdéskört, az egyik hallgató reflektált a fogyatékossággal élö emberek társadalompolitikai aspektusaira, az egyenlötlenség, megkülönböztetés etikai vonatkozásaira. A hallgatók reakciói segítettek abban, hogy egyre inkább tudatosan szemlélhessék az elöítéleteket és téves elképzeléseket, amellyel a marginalizálódott társadalmi csoportokat illetik. A befogadó oktatás (3) témájával kapcsolatosan a kutatás kezdetén gyüjtött kérdőíves adatfelvétel azt mutatta, hogy a hallgatóknak sztereotip elképzeléseik vannak az egyes kisebbségi csoportok irányában. Reflexióikból azonban az derül ki, hogy a kurzus során sikerült ezeket a sztereotípiákat átkonstruálni, ezáltal tudatosabbá válni a jövőbeli inkluzív oktatásban betöltendő szerepüket illetően. A folyamat során a hallgatók tágabb szociokulturális perspektívából közelítettek a kirekesztés felé, és megkérdőjelezték annak létjogosultságát. Az együttmüködés (4) és a tudatosság (5) szükségessége is megfogalmazódott a naplókban.

A kutatások demonstrálták, hogy a reflexió írása során a hallgatók támogató tanulói környezetben hatékonyan szembesülhetnek etikai, társadalmi igazságosságot felvető kérdésekkel. Ezáltal a tanulók a reflexió magasabb szintjére emelkedve, társadalmi kontextusból tekinthetnek erre a témára, a diverzitás elfogadásának szintjéről az etikai döntéshozatal szintjéig juthatnak, és megerősítést kaphatnak a minőségi inkluzív oktatás felé való elköteleződéshez. 


\section{Összegzés}

Jelen tanulmány a reflektív naplók tanárképzésben betöltött szerepét vizsgálta. A reflektív napló a reflektív gondolkodás egyik lehetséges fejlesztő eszközeként van jelen az oktatásban. Mint kutatási eszköz is alkalmazható, tartalmának elemzése számos olyan adatot szolgáltat számunkra, amelyen keresztül meghatározhatjuk azokat a területeket, amelyeken a naplóírás hatással van a hallgatók fejlődésére. A kutatások rámutatnak, hogy a reflektív naplók alkalmazása számos formában lehet jelen a tanárképzésben. Segítheti az elméleti oktatást azáltal, hogy a hallgatók megadott szempontok alapján reflektálnak a feldolgozott tananyagra. A reflektivitás különböző szintjeit leíró modellek a tanárképzés számára elméleti keretként is szolgálhatnak, továbbá alapot biztosíthatnak a kurzusok értékelési kritériumainak meghatározásához. A reflektív naplók alkalmazása a hallgatók tanítási gyakorlatának folyamatát is támogathatja, tudatossá teheti az egyes módszerek és eszközök egyénre szabott és szituációhoz igazított választását.

A reflektív naplók alkalmazása során nehézségekkel is szembesülhet az oktató. A kutatások rámutatnak, hogy legtöbbször egy bevezető kurzusra volt szükség ahhoz, hogy a hallgatókkal elsajátíttassák a reflektív naplóírás elméletét és gyakorlatát, mivel legtöbbjük számára ismeretlen volt a reflektív gondolkodás gyakorlata. Az oktatók számára így többletmunkával járhat a reflektív naplók alkalmazása a kurzus során, mivel egyrészt meg kell ismertetniük a hallgatókkal ennek elméletét és gyakorlatát, másrészt pedig a naplók folyamatos feldolgozása, értékelése, a bejegyzésekre adott naprakész visszajelzések megírása is kihívást jelenthetnek az oktatók szempontjából.

Az elemzett kutatások eredményei azt mutatják, hogy a tanárszakos hallgatók képzésében a reflektivitás három területen segítheti a hallgatók szakmai fejlődését. Hatással lehet reflektivitási szintük növelésére, szakmai fejlődésükre, illetve segítheti őket a társadalmi sokszínüséggel kapcsolatos attitüdjeik, nézeteik formálásában. Szakmai fejlődésük tekintetében elsősorban a tanítási gyakorlatuk területére fókuszálódott a hallgatók reflexiója. Hangsúlyozták, hogy a reflexió által hatékonyabbnak érezték magukat a megfelelő eszközök, módszerek kiválasztásában, illetve konkrétabbá vált elméleti tudásuk. Emellett a kutatások arról is beszámoltak, hogy a reflektív tanulás során megváltoztak a hallgatók tanítással kapcsolatos nézetei, illetve reflektív gyakorlatuk is fejlődött.

A naplók elemzése azt is feltárja, hogy milyen feltételek mellett valósulhat meg ez a fejlődés. Az egyik fontos kitétel az oktatói támogatás, mind a reflektivitás szintjeit illető 
továbblépés, mind pedig a reflexiót elősegítő instrukciók tekintetében. A másik meghatározó feltételnek pedig az időtényező bizonyult: a hallgatók számára elegendő időt kell ahhoz biztosítani, hogy elsajátítsák és alkalmazzák a reflektivitás magasabb szintjeit. Éppen ezért javasolt, hogy a pedagógusképzés teljes hosszában valamilyen formában legyen jelen a reflektivitás fejlesztése.

Egy reflektíven gondolkodó, reflektív gyakorlatokat ismerő és alkalmazó tanárszakos hallgatóból jó eséllyel válik reflektíven gondolkodó pedagógus. Ez pedig elengedhetetlen feltétele annak, hogy a pedagógus szakma végre igazi professzióvá váljon.

\section{Irodalom}

Acquah, E., Szelei, N. \& Katz, H. (2020). Using modelling to make culturally responsive pedagogy explicit in preservice teacher education in Finland. British Educational Research Journal, 46(1), 122-139. DOI: 10.1002/berj.3571

Abu Jado, S. (2015). The Effect of using Learning Journals on Developing Self-Regulated Learning and Reflective Thinking among Pre-Service Teachers in Jordan. Journal of Education and Practice, 6(5), 89-104.

Aldahmash, A., Alshmrani, S. \& Almufti, A. (2017). Secondary school science teachers'views about their reflective practices. Journal of Teacher Education for Sustainability, 19(1), 43-53. DOI: 10.1515/jtes2017-0003

Alger, C. (2006). 'What went well, what didn't go so well': growth of reflection in pre-service teachers. Reflective Practice, 7(3), 287-301. DOI: 10.1080/14623940600837327

Angela, C. \& Feng, S. (1994). A reflection on reflective practice in teaching English to speakers of other languages. Position Papers, 1-10.

Arrastia, M., Rawls, E., Brinkerhoff, E. \& Roehrig, A. (2014). The nature of elementary preservice teachers' reflection during an early field experience. Reflective Practice, 15(4), 427-444. DOI: 10.1080/14623943.2014.900018

Bean, T. \& Zulich, J. (1989). Using dialogue journals to foster reflective practice with preservice, content-area teachers. Teacher Education Quarterly, 16(1), 33-40.

Bentley-Williams, R. \& Morgan, J. (2013). Inclusive education: pre-service teachers' reflexive learning on diversity and their challenging role. Asia-Pacific Journal of Teacher Education, 41(2), 173-185. DOI: 10.1080/1359866x.2013.777024

Bolin, F. (1988). Helping student teachers think about teaching. Journal of Teacher Education, 2, 48-54. DOI: $10.1177 / 002248718803900209$

Cengiz, C. \& Karataş, F. (2015). Examining The Effects of Reflective Journals on Pre-service Science Teachers' General Chemistry Laboratory
Achievement. Australian Journal of Teacher Education, 10, 125-146. DOI: 10.14221/ajte.2015v40n10.8

Clift, R. \& Houston, W. (1990). The potential for research contributions to reflective practice. In Clift, R., Houston, W. \& Pugach, M. (szerk.), Encouraging reflective practice in education: An analysis of issues and programs. New York: Teacher College Press. 208-224.

Cohen-Sayag, E. \& Fischl, D. (2012). Reflective Writing in Pre-Service Teachers' Teaching: What does it Promote? Australian Journal of Teacher Education, 37(10), 20-36. DOI: 10.14221/ajte.2012v37n10.1

Collin, S., Karsenti, T. \& Komis, V. (2013). Reflective practice in initial teacher training: Critiques and perspectives. Reflective Practice: International and Multidisciplinary Perspectives, 14(1), 104-117. DOI: 10.1080/14623943.2012.732935

Collina, S. \& Karsentib, T. (2011). The collective dimension of reflective practice: The how and why. Reflective Practice, 12(4), 569-581. DOI: 10.1080/14623943.2011.590346

Darling-Hammond, L. (2006). Constructing 21st-century teacher education. Journal of Teacher Education, 57(3), 300-314. DOI: 10.1177/0022487105285962

DeCapua, A., Marshall, H. \& Frydland, N. (2018). The Transformational Learning Journey of a Novice ESL Teacher of Low-literate Adults. Journal of Transformative Education, 16(1), 17-38. DOI: $10.1177 / 1541344617704645$

Ersözlü, Z. \& Arslan, M. (2009). The effect of developing reflective thinking on metacognitional awareness at primary education level in Turkey. Reflective Practice, 10(5), 683-695. DOI: 10.1080/14623940903290752

Farrell, T. (2006). Reflective practice in action: A case study of a writing teacher's reflections on practice. ESL Canada Journal, 23(2), 77-90. DOI: 10.18806/tesl.v23i2.56

Francis, D. (1995). The reflective journal: A window to preservice teachers' practical knowledge. Teaching and Teacher Education, 11(3), 229-241. DOI: 10.1016/0742-051x(94)00031-z 
Freire, P. (2005). Pedagogy of the oppressed. New York: Continuum.

Garmon, M. (1998). Using dialogue journals to promote student growth in a multicultural education course. Remedial and Special Education, 19(1), 32-45. DOI: 10.1177/074193259801900104

Gay, G. (2013). Teaching to and through cultural diversity. Curriculum Inquiry, 43(1), 48-70. DOI: 10.1111/curi.12002

Good, J. \& Whang, P. (2002). Encouraging reflection in preservice teachers through response journals. The Teacher Educator, 37(4), 254-267. DOI: 10.1080/08878730209555299

Hatton, N. \& Smith, D. (1995). Reflection in teacher education: Towards definition and implementation. Teaching and Teacher Education, 11(1), 33-49. DOI: 10.1016/0742-051x(94)00012-u

Jay, J. \& Johnson, K. (2002). Capturing complexity: a typology of reflective practice for teacher education. Teaching and Teacher Education, 18, 73-85. DOI: 10.1016/s0742-051x(01)00051-8

Kazu, H. \& Demiralp, D. (2015). Usage status of methods that enhance reflective thinking in primary level programs. International Online Journal of Educational Sciences, 4(1), 131-145.

Kim, M. (2018). Pre-service Teachers' Reflective Journal Writing on Practicum: Focus of Reflection and Perceptions. Modern English Education, 2, 30-41. DOI: 10.18095/mee.2018.19.2.04

Kinsella, E. (2007). Embodied reflection and the epistemology of reflective practice. Journal of Philosophy of Education, 41(3), 395-409. DOI: 10.1111/j.1467-9752.2007.00574.x

LaBelle, J. \& Belknap, G. (2016). Reflective journaling: fostering dispositional development in preservice teachers. Reflective Practice, 17(2), 125-142. DOI: 10.1080/14623943.2015.1134473

Ladson-Billings, G. (1995). Toward a theory of culturally relevant pedagogy. American Educational Research Journal, 32(3), 465-491. DOI: $10.3102 / 00028312032003465$

Ladson-Billings, G. (2014). Culturally relevant pedagogy 2.0: Aka the remix. Harvard Educational Review, 84(1), 74-84. DOI: 10.17763/ haer.84.1.p2rj131485484751

Langer, A. (2002). Reflecting on practice: Using learning journals in higher and continuing education. Teaching in higher education, 7(3), 337-351. DOI: $10.1080 / 13562510220144824$

Lee, H. (2005). Understanding and assessing preservice teachers' reflective thinking. Teaching and Teacher Education, 21(6), 699-715. DOI: 10.1016/j. tate.2005.05.007
Lee, I. (2008). Fostering preservice reflection through response journals. Teacher Education Quarterly, 35(1), 117-139.

Lowe, G., Prout, P. \& Murcia, K. (2013). I see, I think, I wonder: An evaluation of journaling as a critical reflective practice tool for aiding teachers in challenging or confronting contexts. Australian Journal of Teacher Education, 38(6), 1-16. DOI: 10.14221/ajte.2013v38n6.6

Lucas, T. \& Villegas, A. (2013). Preparing linguistically responsive teachers: Laying the foundation in preservice teacher education. Theory into Practice, 52, 98-109. DOI: 10.1080/00405841.2013.770327

Maarof, N. (2007). Telling his or her story through reflective journals. International Education Journal, 8(1), 205-220.

Mair, C. (2010). Structured reflection facilitates metacognitive awareness and learning. 35th Improving University Teaching Conference, Washington, DC.

Nolan, A. \& Sim, J. (2011). Exploring and evaluating levels of reflection in pre-service early childhood teachers. Australasian Journal of Early Childhood, 36(3), 122-130. DOI: 10.1177/183693911103600316

Nurfaidah, S., Lengkanawati, N. S. \& Sukyadi, D. (2017). Levels of Reflection in EFL Pre-Service Teachers' Teaching Journal. Indonesian Journal of Applied Linguistics, 7(1), 80-92. DOI: 10.17509/ijal. v7i1.6861

Park, C. (2003). Engaging students in the learning process: The learning journal. Journal of Geography in Higher Education, 27(2), 183-199. DOI: 10.1080/03098260305675

Pnina, S. \& Anat, M. (2019). The contribution of reflective thinking to the professional development of pre-service teachers. Reflective Practice, 20(4), 548-561. DOI: 10.1080/14623943.2019.1642190

Pollard, V. (2008). Ethics and reflective practice: Continuing the conversation. Reflective Practice, 9(4), 399-407. DOI: 10.1080/14623940802431788

Porter, P., Goldstein, L., Leatherman, J. \& Conrad, S. (1990). An ongoing dialogue: Learning logs for teachers. In Richards, J. \& Nunan, D. (szerk.), Second language teacher education. Cambridge UK: Cambridge University Press. 227-240.

Rogers, R. (2001). Reflection in higher education: A concept analysis. Innovative Higher Education, 26, 37-57. DOI: 10.1023/a:1010986404527

Scales, P. (2008). Teaching in the Lifelong Learning Sector. New York: Open University Press.

Schön, D. (1987). Educating the refl ective practitioner. San Francisco: Jossey-Bass.

Shavit, P. \& Moshe, A. (2019). The contribution of reflective thinking to the professional development of pre-service teachers. Reflective Practice, 20(4), 548-561. DOI: 10.1080/14623943.2019.1642190 
Stenberg, K., Rajala, A. \& Hilppo, J. (2016). Fostering theory-practice reflection in teaching practicums. Asia-Pacific Journal of Teacher Education, 44(5), 470-485. DOI: 10.1080/1359866x.2015.1136406

Syslova, Z. (2015). The level of reflection in the professional development of pre-primary teachers. Przeglad Pedagogiczny, 1, 73-84.

Szivák Judit (2014). Reflektiv elméletek, reflektiv gyakorlatok. Budapest: ELTE Eötvös Kiadó.

Szivák Judit, Gazdag Emma \& Nagy Krisztina (2018). Szisztematikus irodalomfeldolgozás a videófelvétellel támogatott felidézést alkalmazó pedagógus-kutatásokról. Neveléstudomány, 7(1), 5-14. DOI: 10.21549/ntny.23.2018.3.1

Thompson, N. \& Pascal, J. (2012). Developing critically reflective practice. Reflective Practice, 13, 311-325. DOI: 10.1080/14623943.2012.657795

Tuan, L. (2010). Enhancing EFL learners' writing skill via journal writing. English Language Teaching, 3(3), 81-88. DOI: 10.5539/elt.v3n3p81
Tuncer, H. \& Ozkan, Y. (2018). A Case Study on Assessing Reflectivity Levels of Pre-Service Language Teachers through Journals. Novitas-ROYAL (Research on Youth and Language), 12(2), 173-186.

Ward, J. \& McCotter, S. (2004). Reflection as a visible outcome for preservice teachers. Teaching and Teacher Education, 20(3), 243-257. DOI: 10.1016/j. tate.2004.02.004

Wilson, J. \& Jan, L. (1993). Thinking for themselves: Developing strategies for reflective learning. Australia: Eleanor Curtain Publishing.

Zhu, G., Iglesia, P. \& Wang, K. (2020). Chinese and Spanish preservice teachers' practicum teaching experiences: a transformative learning perspective. Journal of Education for Teaching, 46(1), 124-128. DOI: 10.1080/02607476.2019.1708623

Zulfikar, T. \& Mujiburrahman. (2018). Understanding own teaching: becoming reflective teachers through reflective journals. Reflective Practice, 19(1), 1-13. DOI: $10.1080 / 14623943.2017 .1295933$

\section{Absztrakt}

Napjaink gyorsan változó információs társadalmában a tanároknak folyamatosan felül kell vizsgálniuk és kihívások elé kell állítaniuk nézeteiket, módszereiket, mivel a sokszínű osztályközösségek, illetve a változó tanulási formák, források és tanulási környezetek gyors, adaptív pedagógiai reakciókat igényelnek (Lampert, 2010). A reflektív gondolkodás elengedhetetlen kelléke a tanárok szakmai repertoárjának, így a 20. század végétől a reflektivitás egyre nagyobb hangsúlyt kap a pedagógusképzésben (Kinsella, 2007; Collin, Karsenti és Komis, 2013).

A tanárszakos hallgatók reflektív gondolkodásának támogatására, illetve feltárására számos módszer áll rendelkezésre mind hazai, mind nemzetközi viszonylatban. Ezeknek a tanulmányoknak szisztematikus feldolgozását célul kitüző kutatások azonban kis számban vannak csak jelen a hazai szakirodalomban.

Jelen tanulmány a reflektív naplónak mint a reflektivitás egyik hatékony eszközének tanárképzésben való alkalmazási lehetőségeit tárja fel a szakirodalmi elemzés módszerével. A kutatásba bevont tanulmányok céljait és eredményeit vizsgálja a reflektív naplóírás tanárszakos hallgatók fejlődésére gyakorolt hatásainak relevanciájában. A reflektív naplókkal kapcsolatos kutatások eredményei rávilágítottak, hogy a naplóírás különböző területen gyakorolhat hatást a tanárrá válás folyamatában. Támogathatja a szakmai tudás elmélyülését, tudatosabbá teheti a tanári gyakorlatot, de segítheti a tanítással kapcsolatos attitüdök, nézetek felülvizsgálatát is Emellett fejlesztheti a tanárszakos hallgatók reflektivitásának szintjét és hozzájárulhat inkluzív szemléletmódjuk kialakításához. 